\title{
Chapter 15 \\ Jordan's Shadow State and Water \\ Management: Prospects for Water Security \\ Will Depend on Politics and Regional \\ Cooperation
}

\author{
Valerie Yorke
}

\begin{abstract}
Over two decades, many have regarded the idea of a Red Sea-Dead Sea (RSDS) Conveyance Project to save the Dead Sea as a golden opportunity for Jordan. It held promise of providing the Kingdom with desalinated water to meet its long-term needs. Now, with the project's potential abandonment, Jordan needs to consolidate and accelerate reforms to close its deficits and improve water sector sustainability until a long-term bulk solution is found. Addressing how these challenges might be dealt with, this chapter focuses on politics. Analysis of Jordan's water reforms over 20 years shows that the sector's limited ability to achieve its goals is rooted in a wider problem - the Kingdom's organisation of political power. The chapter explores how an evolving "political compact" between Throne and people, underpinned by patronage, permitted an increasingly powerful neopatrimonial, anti-reformist elite - a resilient "shadow state" - to influence policies and control the economy including in due course water resources. The water problem cannot therefore be remedied only through improved water management. Taking account of the link between political dynamics and governance, the chapter sets criteria for implementing reforms that, if met, would gradually free policymaking and institutions from shadow-state influence, providing context for effective water solutions. A final section, addressing the need for a nationwide coordinated approach to comprehensive water reforms that could provide a path to water security, discusses how Jordan might accelerate policies underway, implement deeper reforms and pursue further options - locally and regionally - to address mediumand long-term challenges.
\end{abstract}

\footnotetext{
This paper draws on research for, and the analysis and data in the author's study, Politics matter: Jordan's path to water security lies through political reforms and regional cooperation, April 2013, commissioned by NCCR-Trade Regulation, World Trade Institute, Bern.

V. Yorke $(\bowtie)$

NCCR Trade Regulation/World Trade Institute, University of Bern, Hallerstr. 6, 3012 Bern, Switzerland

e-mail: v.yorke@btinternet.com
} 
Keywords Jordan water scarcity • Water governance shortcomings $~$ Politics of water $\bullet$ Shadow state networks $\bullet$ National and regional solutions $\bullet$ Cooperation $\bullet$ Water security $\bullet$ Water demand $\bullet$ Water supply $\bullet$ RSDS Conveyance Project

\subsection{Defining the Problem}

Jordan faces a deepening water crisis, aggravated over decades by climatechange impacts, regional conflict, inflows of migrants and poor governance. Its people are among the most water-deprived worldwide, with $145 \mathrm{~m}^{3} /$ year per person (2008) (MWI 2009, p. 3-1), a level projected to fall as the gap between demand for water and renewable and financed non-renewable supplies widens. Few in-country options remain to develop new water. Meanwhile, with more than $80 \%$ of available annual supply of up to $900 \times 10^{6} \mathrm{~m}^{3}$ depending on unsustainable abstraction from groundwater aquifers and on diminishing transboundary surface flows, Jordanians could face absolute water poverty by 2025 , with only $90 \mathrm{~m}^{3}$ per person (USAID 2012, p. vii). MWI statistics for 1994-2010 (Fig. 15.1) also reveal continuing structural distortions in water use: agriculture remained the dominant consumer $(66 \%)$, whilst contributing only $3.5 \%$ of GDP (MWI and WRG 2011, p. 23); the municipal sector modestly increased its share $(30 \%)$ and industry/tourism use remained low (4.5-7\%). Behind these data lie dangerous trends, namely continuing overpumping of groundwater aquifers; continuing inefficient water use in terms of productivity and diminishing scope to cope with climate-change impacts.

\subsubsection{Demand Exceeds Supply}

In terms of numbers, the scale of the challenge facing Jordan to 2025 and beyond of securing water to provide for its expanding population and meet its economic growth aspirations is crystal clear. Recent demand and supply projections in studies using different methodologies all show substantial deficits (MWI and WRG 2011; Coyne et Bellier 2012; USAID 2012). These differ in size, however. In order, therefore, to reflect the extent of the problem as realistically as possible, alternative projections - based on the MWI's annual water budget of 2012, but stripped of outdated or uncertain assumptions (Yorke 2013, pp. 25-27) - are provided at Fig. 15.2.

They show widening deficits, reaching $630 \times 10^{6} \mathrm{~m}^{3} /$ year by 2025 , the implications of which are well recognised: Jordan needs a costly new bulk supply source for the long term and meanwhile demand will likely continue to be met by overabstracting valuable low-cost renewable supplies. 


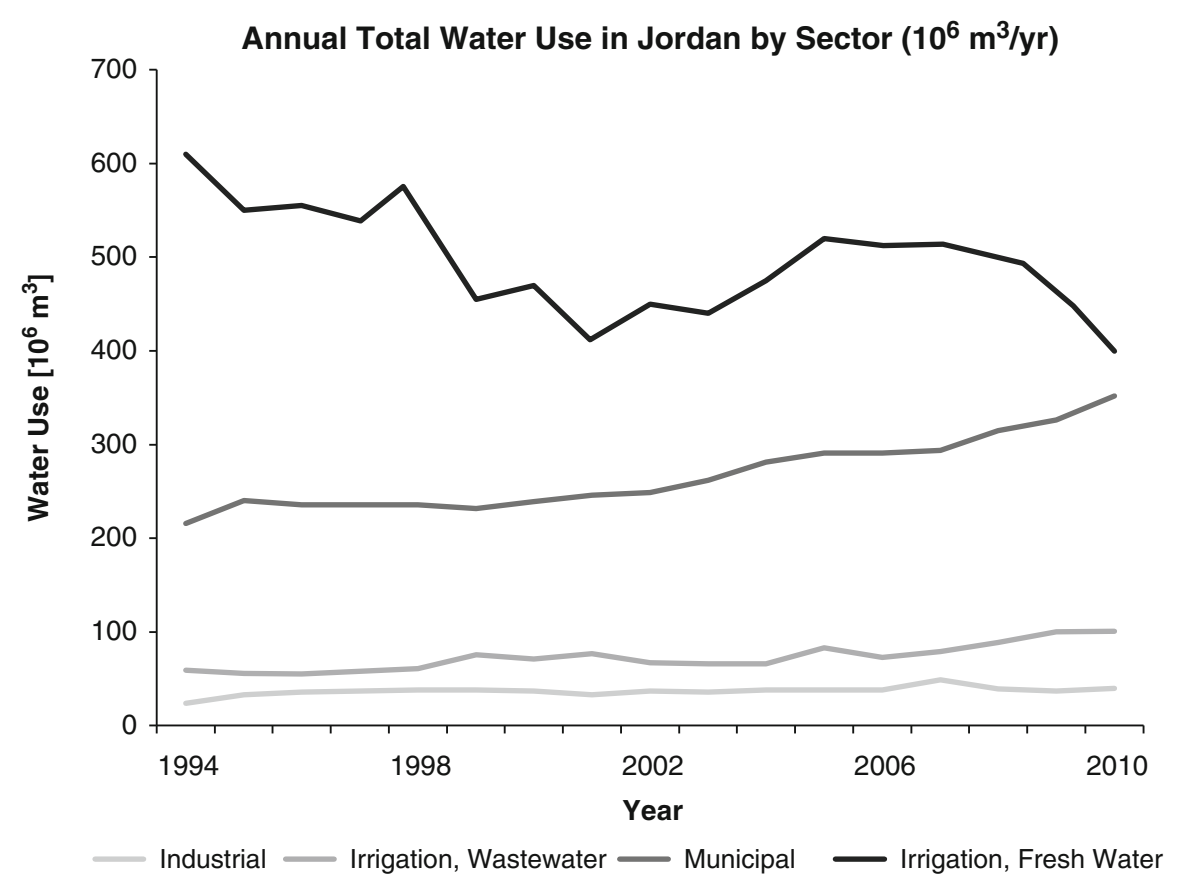

Fig. 15.1 Total water use in Jordan by sector since $1994\left(10^{6} \mathrm{~m}^{3}\right)$ (Source: MWI Water Budget 2009/2010, MWI Water Resources Directorate open files, 2011. Cited in USAID (2012, p. viii))

\subsubsection{Unpredictable Transboundary Flows}

Seen through the lens of shared resources, the problem becomes more serious. Arid Jordan is already vulnerable to multi-year drought (JME 2009, p. 31). Its geostrategic location and the legacy of regional conflict combined with heightened regional instability add to uncertainties. This is because a significant proportion of the surface and renewable groundwater providing most of Jordan's water derive from transboundary flows. Jordan is located downstream from Syria and Israel, with whom waters of the River Yarmouk and River Jordan respectively are shared (Yorke 2013, pp. 120-123). Aggravating matters, bilateral agreement on joint management of cross-border surface supplies ${ }^{1}$ is either non-existent (1987 Jordan-Syria accord) or inadequate (Jordan-Israel Peace 1994, Annexes II, IV) and Jordan receives less than its rightful shares (SFG 2011, p. 26; MWI 2012). Meanwhile, fossil water

\footnotetext{
${ }^{1}$ The problem also surrounds groundwater. Of eleven renewable groundwater reservoir basins, four are shared with Syria (Yorke 2013, pp. 16-17).
} 


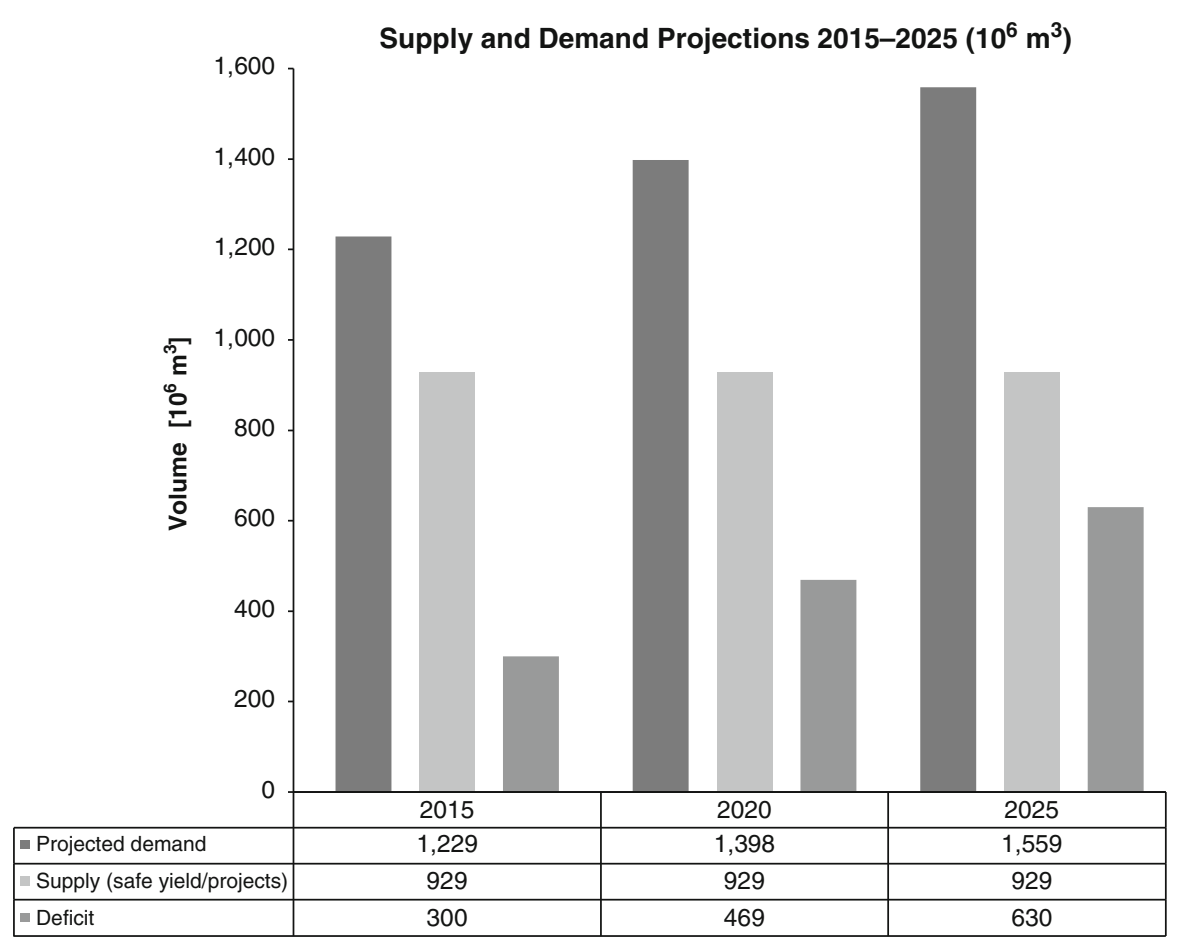

Fig. 15.2 Author's summary of supply (safe yield/projects underway) and demand projections, 2015-2025 $\left(10^{6} \mathrm{~m}^{3}\right)$ (Source: Cited in Yorke (2013, pp. 28-29). Based on MWI (Jordan Ministry of Water and Irrigation) (2012)). Notes: Overall supply of $929 \times 10^{6} \mathrm{~m}^{3}$ to 2025 comprises (1) sustainable supply calculated at $776 \times 10^{6} \mathrm{~m}^{3}$ (total supplies of $892 \times 10^{6} \mathrm{~m}^{3}$ in 2010 minus over abstraction of $76 \times 10^{6} \mathrm{~m}^{3}$ minus $40 \times 10^{6} \mathrm{~m}^{3}$ irrigation use of Disi resources); (2) new water supply: Disi-Amman conveyor $\left(100 \times 10^{6} \mathrm{~m}^{3} /\right.$ year $)$, As Samra Wastewater Plant Extension $\left(45 \times 10^{6} \mathrm{~m}^{3} /\right.$ year), Kufranjah dam $\left(5 \times 10^{6} \mathrm{~m}^{3} /\right.$ year $)$, small wastewater plants $\left(3 \times 10^{6} \mathrm{~m}^{3} /\right.$ year $)$. Projections exclude a possible $100 \times 10^{6} \mathrm{~m}^{3}$ desalination plant near Aqaba and supply side efficiency projects. Demand projections are based on MWI statistics

beneath Jordan's border with Saudi Arabia accounts for $8 \%$ of overall supply, ${ }^{2}$ but the two states have no accord. Inevitably, absent treaty-based or more formal agreement, inadequate water governance fuels bilateral suspicions.

The question arises whether this modus vivendi on water use is sustainable. According to the World Bank, the Middle East is especially vulnerable to climate change (World Bank 2007). With average temperatures expected to rise and precipitation levels to decline, Jordan's freshwater availability is projected to fall by $15 \%$ by 2020 (SFG 2011, p. 92). Climate change-induced water stress, impacting agriculture, economic growth, health and food security, could potentially excite unrest and fuel tensions over water with neighbours.

\footnotetext{
${ }^{2}$ Disi resources have been used since the early 1980s for municipal and industry purposes in Aqaba and later for agriculture; since $2013100 \times 10^{6} \mathrm{~m}^{3} /$ year have been pumped to supply Amman.
} 


\subsubsection{Governance Shortcomings}

Jordan's water governance record provides a third perplexing perspective. With vital national and human security interests at stake, Jordan has published strategies and introduced donor-supported reforms, targeting demand management, over more than two decades. But, these efforts have been insufficient to narrow worsening water deficits, protect groundwater and pre-empt the disaster to which the country is heading. Consider the balance-sheet during the two decades to 2010 .

\subsubsection{Reducing Unsustainable Highlands Groundwater Abstraction}

After 1997 demand management focused on reducing groundwater use for irrigated agriculture especially in the Highlands, where it consumes up to half of abstracted water. The landmark Groundwater By-Law No 85 (2002) sought to control abstraction through block tariffs, penalising the abuse of licensed withdrawal levels and closing illegal wells (FOEME 2010). ${ }^{3}$ These moves proved insufficient - in 2010, withdrawals from renewable aquifers still exceeded safe yield by an average $55 \%$ (and by 176 and $215 \%$ in the Amman-Zarqa and Azraq basins, according to (GIZ 2011; Subah and Habjoka 2011; MWI 2012). Water institutions acting alone lacked the capacity - both authority and back-up from the ministries of interior and agriculture - to enforce regulations on drilling and private sales and to effectively monitor and close wells. Compounding matters and in the knowledge of donors, two major donor-funded initiatives, the Water Demand Management Unit and the USAID's Instituting Water Demand Management failed to target agriculture (Yorke 2013, p. 43). ${ }^{4}$

\subsubsection{Encouraging Efficient Water Use}

From 1997, the importance of pricing and incentives to encourage more efficient water use and to raise revenue was also recognised. Reflecting Jordanian-donor collaboration, Jordan's Water Strategy (JWS) of 2009 called for cost-reflective tariffs for the long term, and the USAID sought to raise awareness on the need to change the way water is valued and allocated.

However, political, historical and social factors limited the sector's capacity to implement its plans, according to officials and water specialists interviewed by the author (Yorke 2013, pp. 43-44). Authority to alter water tariffs or remove tariffs on

\footnotetext{
${ }^{3}$ The By-Law created a $150,000 \mathrm{~m}^{3} /$ year quota of free abstraction for each well, with block tariffs for further amounts abstracted. A 2004 amendment, providing for changes in these tariffs in 2008, was not implemented.

${ }^{4}$ According to the USAID Office of Inspector General's 2011 audit, USAID/Jordan had no project focusing on agriculture's water use and conditions precedent no longer required the government to address water use in agriculture. Jordan officials had also requested the mission to drop the condition on closing 50 illegal wells.
} 
inter alia agricultural imports lies with the cabinet - not with the sector; and historically, low tariffs have helped to protect the poor and farmers working at the margins. Meanwhile, government focus on new supplies to deliver water security silenced debate on the need for efficient and fairer allocation; while access to "virtual water" helped to disguise the scale of the crisis and the need for increased demand management (Allan 2003).

With these constraints, the 1997 tariff system, with its 2002 By-Law revisions, remained unchanged, despite USAID making cash transfers for GOJ projects conditional on agreed steps towards full cost recovery, including raising tariffs (USAID 2011, p. 8). Agriculture continued to pay less for water than the municipal and industry sectors - and below the cost of delivery. Low prices and import tariffs worked against commitments to improve end-use efficiency reduce waste and increase conservation. They distorted allocations so farmers lacked incentive to switch to higher-value water-efficient crops. Agriculture's share of renewable water declined, but not significantly; and overall, the Highlands area given to irrigation increased (Hagan 2008, p. 32).

\subsubsection{Reducing Non-Revenue Water (NRW)}

The high level of NRW - water supplied that raises no revenue - represents huge waste of low-cost water supply (Salameh 2007; MWI 2009). With an average $45-47 \%$ of water pumped through supply works lost to NRW, an estimated $137 \times 10^{6} \mathrm{~m}^{3}$ of the total $320 \times 10^{6} \mathrm{~m}^{3}$ municipal allocation would have been lost in 2009 (Denny et al. 2008, p. 10; MWI 2009, pp. 3-2). The government has reiterated the need to reduce NRW - with the JWS aiming to reduce the level to $25 \%$ through addressing leakages, illegal pumping and meter deficiencies. Despite huge expenditure on infrastructure, corporatisation of utilities and donor projects to improve efficiency, reductions have not been significant.

One reason has been the slow pace of privatisation owing to political opposition. The government favours private-sector involvement in water and wastewater services in order to attract investment and implement reforms to improve financial sustainability. But by 2011, only three utility companies, owned by the Water Authority of Jordan (WAJ), had been established and their operations corporatised. ${ }^{6}$ Moreover, results were mixed. The Aqaba Water Company (AWC) reduced NRW levels significantly, but Miyahuna (Amman) and the Yarmouk Water Company (YWC) recorded continuing high losses $-35.3 \%$ and $40.8 \%$, together accounting for an estimated average annual loss to NRW of $77 \times 10^{6} \mathrm{~m}^{3}$ of a total $80 \times 10^{6} \mathrm{~m}^{3}$ for the three companies (USAID 2012). Poor performance was reportedly mainly due to distribution practice of undersupply and rationing, since intermittent flows

\footnotetext{
${ }^{5}$ The term coined by Professor Tony Allan refers to water used to produce grain and food imports. ${ }^{6}$ In 2007, the original Amman private operator was substituted by Miyahuna, a company owned by WAJ with private involvement. The AWC and YWC were similar companies established in 2004 and 2011 respectively.
} 
damage pipes. The second reason cited to the author was the loss of resources from the grid and illegal wells, through theft - resulting from lax enforcement and lenient penalties.

\subsubsection{Reforming Water Institutions}

Decision-makers have long recognised that developing sector institutional capacity to manage and deliver efficient operations would be a pre-requisite for coping with the water crisis. Progress was blocked, however, due to the sector's inability to sort the overlapping responsibilities of the MWI and the government-owned WAJ and Jordan Valley Authority (JVA) - all three with ties to traditional constituencies, and the conflicts of interest these generated: MWI planning and projects were hampered by a lack of overall responsibility for supplies; the WAJ's dual supply and retail roles complicated water management but their separation remained politically constrained; lack of agreement over use of multiple data sources hindered sector planning; and over-staffed institutions suffered from low morale and a "brain drain".

The above record demonstrates that despite some achievements, efforts were $a d$ hoc and partial and failed to set in train transformative reforms that could significantly change water outcomes. The sector lacked capacity on its own to fulfil its goals in key areas, was inhibited by factors outside the sector and disadvantaged by weak organisation. Overall, this suggests Jordan's water crisis is not only one of supply and demand, but also one of national governance. Understanding why this is so requires consideration of a wider structural problem.

\subsection{The Shadow State}

\subsubsection{The Politics of Co-option}

The longevity of Hashemite rule and Jordan's present governance problems are linked. Both are rooted in the distinctive organisation of power to which state formation and Hashemite rule gave rise, and in its restructuring over time (Yorke 1988, 1990). In Jordan, as in other Middle East states formed on the back of colonial legacy and weak institutions, personalised leadership based on patron-client relations, underpinned by patronage and lubricated by outside rents, remains key. ${ }^{7}$ Although the Kingdom has a constitution and formal executive, legislative and judicial structures over which the king enjoys broad powers, Hashemite rule has been underpinned by parallel informal neo-patrimonial structures, which bind military and civilian elites into a web of support, and by a costly "social contract" between Throne and people. Patronage underpins the system: privileges, benefits and cheap

\footnotetext{
${ }^{7}$ A. Peters and P.W. Moore provide a valuable account of rentierism (Peters and Moore 2009, pp. 256-285).
} 
services - today, including access to water - are exchanged for allegiance. Over time, however, the political influence and sense of entitlement accompanying privileges and benefits transferred has eroded the monarchy's autonomy.

In the face of changing circumstances - the challenges of state formation, panArabism, nationalism, war, migration and development, and the economy's downturn in the 1980s - the Hashemites pursued imaginative co-option policies to consolidate power and maintain stability. In the process, the organisation of power and its location would alter, with consequences for decision-making, and the strength of the king's role in it. What amounted to an evolving political bargain between Throne and people permitted influential traditional elites and businessmen, enjoying a variety of privileges, to become embedded in a web of power - or shadow state (Tripp 2007, pp. 4-5), whose influence today penetrates the core elite, military and intelligence, bureaucracy and parliament. Understanding the power dynamics of these "shadow" networks whose growing influence afforded special interest groups opportunity to resist change and influence policies to protect their interests at the expense of those of the state (Muasher 2011), sheds light on the water governance deficits of the last two decades.

Transjordan's creation in March 1921 under Amir Abdullah was the result of an historic opportunity seized by the British to contain French expansion in the region. Transjordan was not a separate political entity and its people's heterogeneity Transjordanians of East Bank origin but also from Arabia and from Palestine before 1948 - complicated the forging of a national identity. Palestinians would come to comprise more than half the population. The presence of non-Arab Circassians, Arab Christians and substantial Iraqi, and today Syrian, communities, as well as rivalries between tribes complicate the picture. Faced with inevitable disintegrative pulls, King Abdullah I and his successor, King Hussein, sought to build a common identity of interest between the Hashemites and their subjects.

The pursuit of a complex process of co-option to keep in with supporters and win the acquiescence of potential opposition would be key to consolidating Hashemite rule, which became embedded in patron-client relations, laying the basis of the "shadow state". Lacking central power, Abdullah courted the tribes with arms, funds and employment in the military and extended patronage to merchants in order to extend state authority - policies facilitated by British subsidies. In the turbulent 1950s and 1960s, the political bargain took on new forms: with flows of unconditional US financial assistance replacing British funds (Peters and Moore 2009), ${ }^{8}$ Hussein responded to the growing demands of East Bank tribes by expanding the army and distributing members of tribes and minorities, his key supporters, through the administration and political structures, while drawing others into state. He rewarded merchants with public-sector jobs and contracts, protected the interests of and provided jobs for Transjordanian and Palestinian critics, and met the needs of Palestinian refugees through US-funded building of infrastructure. Arab aid flows during the 1970s' oil boom contributed to funding growing state largesse. Thus the king was able to subordinate Transjordanian traditional elites - and potential challengers amongst them - to the influence of the state and give the Palestinians a stake in the

\footnotetext{
${ }^{8}$ Military spending increased by $74 \%$ in $1955-1960$ and tripled in 1961-1975.
} 
country. Stability of Hashemite rule was enhanced through crafting a social balance where social groups offset each other's influence. Cohesion appeared to prevail.

\subsubsection{Politics of Water}

It is in the context of these Hashemite regime maintenance policies and evolving organisation of power to which they led that the role of water provision today - for agricultural and domestic purposes - is best understood. With growing water scarcity, water has become a political matter - serving as a political instrument to maintain support, a source of personal wealth and influence for elites to be won and protected, and a cheap service as part of the "social contract" with the people.

The critical importance to King Abdullah I and his successors of co-opting powerful traditional and merchant landowners would from the start put agriculture at the centre of patronage politics, with forms of exchange around water in later years becoming an integral part and benefiting a widening constituency. An early indication came with British-designed land reforms that benefited Abdullah's landowning supporters - tribal leaders, peasants, and merchants (Fischbach 2000, pp. 209-212). In the process, they assisted many sheikhs to increase their holdings and influence (Alon 2009, pp. 127-128). By the turbulent 1950s, King Hussein was able to continue to fund privileges for tribal farmers whilst simultaneously financing development, urbanisation and services for the population - hugely expanded as a result of the 1948 war with Israel: US-funded water projects were key in settling Palestinian refugees in the Jordan Valley, but land irrigation projects also benefited tribal favourites and their followers (Peters and Moore 2009, p. 271). Landowners benefited from political rewards, too, as Hussein sought to consolidate loyalties in the wake of pan-Arabist pressures in the 1950s and the Palestinian rebellion in 1970/1971. Members of landowning families were appointed to key army and government posts - those of prime minister and defence minister, as well as in the agriculture, water and planning ministries (Yorke 2013, p. 67). ${ }^{9}$ With this privileged access, traditional elite groups became entrenched. Embedded in politics and the administration, they were well-placed to advance their interests and preferred water policies in the Jordan Valley and Highlands.

Later in the 1980s, when the Hashemites sought to compensate key constituencies for economic setbacks as a result of the faltering economic boom and the subsequent IMF-imposed structural adjustment program, political liberalisation brought new kinds of pay-offs providing opportunity for these elites to consolidate their stakes in farming and in access to renewable and fossil groundwater. Henceforth influential landowners and farmers in the Northern Highlands and in Disi in the south, for example, were able to lobby inter alia for access to water for their farms,

\footnotetext{
${ }^{9}$ Hazza Al-Majali was twice prime minister $(1955,1959)$ and minister of agriculture (1950-1951) and Field Marshall Habis Al-Majali, his cousin, was chief of staff (1958-1975), defence minister (1967-1968), member of the Upper House 1967, 1984, 1989, 1993, and 1997. Adnan Badran was prime minister in 1989.
} 
using their public positions in parliament and politics and links to the centre for private gain - all with grave implications for the water sector.

\subsubsection{Northern Highlands}

In the Northern Highlands where Jordan's population has historically been concentrated, farming pre-dates the state's formation. Thus, from the 1920s, the political exchanges around land were key to binding Highland farmers to Amir Abdullah and to underpinning state consolidation. They laid the foundation for today's patronage state which would take on its own logic.

As noted earlier, Transjordanian landowners would increase their political influence and come to dominate land ownership and agricultural markets. Early on, larger Highland landowners had benefited from British land reforms, and many still today maintain the legal rights acquired then (Alterman and Dziuban 2010). With land their main source of wealth, they cooperated with merchants in parliament to influence government resource policy. Meanwhile, the Hashemites - in confronting pan-Arabist and Palestinian nationalist challenges - extended generous privileges to these key Highland constituents. They benefited from light regulation of their farming affairs, from government investment in agriculture to provide jobs and food for the expanding population and from the establishment of well fields to exploit groundwater aquifers (Hagan 2008, p. 16). Agricultural expansion in the 1960s and 1970s paved the way for a huge increase in irrigated agriculture - in later decades using groundwater pumped from depleting aquifers (Hagan 2008, p. 32). As a result, in 1997, when the government launched its groundwater strategy to protect the sustainability of vital renewable resources, powerful landowners resisted. By-Law No 85 was eventually passed in 2002, but its provision to close illegal wells was not implemented - under a 2004 amendment, illegal wells could register for inclusion in the MWI monitoring program. Quotas and bulk tariff rates to encourage efficiency were introduced, but these remained virtually unchanged thereafter, and, until recently, fees, even for legal wells, were often not collected. Astonishingly, farmers reportedly used groundwater for new plantings of low value olive trees (per $\mathrm{m}^{3}$ of irrigation water used) in order to enhance land values (USAID 2012, p. 34).

\subsubsection{Southern Highlands}

In the 1980s, the government started large-scale farming around the Disi aquifer in the south in an effort to make Jordan self-sustainable in wheat and barley. Private landowners and commercial elites would benefit: the government soon sold its farm to the Al Masri family and offered cheap land near the aquifer to private farm companies, whose shareholders included former government officials (Yorke 2013, pp. 69-70). ${ }^{10}$

\footnotetext{
${ }^{10} 25$-year contracts provided cheap land and allowance of $1,000 \mathrm{~m}^{3} / \mathrm{dunum} / \mathrm{year}$ to the companies, which in return would use $50 \%$ of land to grow wheat and barley for government purchase $\left(1\right.$ dunum $\left.=1,000 \mathrm{~m}^{2}\right)$.
} 
Twenty years later public controversy surrounded Disi farming over its inefficient use of up to $65 \times 10^{6} \mathrm{~m}^{3} /$ year (equivalent to almost a third of annual municipal supplies in 2007) of precious non-renewable drinking water. ${ }^{11}$ But private criticism, relayed by interviewees to the author in 2010 , focused on the "shadow state". Disi farming was viewed as symptomatic of the political power wielded by vested interests and the government's lack of political will to act in the state interest to curb corrupt practice. Of special concern was rent-seeking by political and business elites through securing policies to promote their farming interests and to provide immunity from those that might undermine them. ${ }^{12}$ Critics argued that government failure to allow the companies' licenses to expire in 2002 and to enforce its decision not to renew the companies' contracts in 2012 reflected the influence of powerful groups with ties to ruling circles and the ministries (Namrouqa 2012).

\subsubsection{Resilience of the Shadow State}

This analysis indicates that the water governance problem is part of a wider problem - the organisation of political power which the regime has shaped and altered over time to maintain security, which has politicised water, today controls resource allocation and inhibits regional cooperation, and in which anti-reformists are entrenched. The water problem cannot therefore be addressed through technical solutions alone. A pre-requisite will be political reforms that reduce the influence of "shadow state" networks over institutions, the economy and policies.

The task will not be easy. The web of power emerging from carefully choreographed co-option to protect Hashemite longevity has proven remarkably resilient (Yorke 2013, pp. 71-75). Despite his significant executive powers, King Abdullah II's reform initiatives after 1999 met resistance from conservative elites (Muasher 2011, pp. 7-23). In the event, he chose to back down rather than risk forfeiting the loyalty of a key constituency. Royal room for manoeuvre was constrained by an absence of sufficient "bottom-up" pressure for reform. ${ }^{13}$ Post-1989 the Throne's new partnership with the people based on the National Charter permitted political parties but constrained political activity, ${ }^{14}$ whilst electoral gerrymandering and the

\footnotetext{
${ }^{11}$ Water experts, Royal Water Committee members and donors shared criticisms: grains that the farms were contracted to produce could be grown more efficiently in the north using recycled water; farms were violating contracts, employing expatriate rather than local workers, and producing water-intensive produce for export rather than cereals for home consumption.

${ }^{12}$ Criticism focused on former government officials benefiting from the companies, on one serving prime minister using his public office to freeze a government tax claim on a company of which he was shareholder, and on the government for ignoring contract violations re growing water-thirsty crops.

${ }^{13}$ Since 1989 unrest has been frequent as a result of neo-liberal policies eating into the patronage state, with quasi-privatisation benefiting those linked to the palace but reducing state sector jobs particularly unpopular.

${ }^{14}$ The National Charter led to the legalisation of parties, but did so in return for acceptance of the constitution and the powers of the monarchy, thus placing boundaries on political activity and marginalising opposition.
} 
"one-man one-vote" system ensured over-representation of traditional elements at the opposition's expense. Moreover, reformists themselves representing the plurality of a fragmented society - sharing goals perhaps, but with distinct orientations have proven no match for anti-reformists of a centralised "shadow state".

Meanwhile, U.S. and Arab Gulf allies have played a key role in shaping this reality through funding the security and patronage networks underpinning Hashemite rule. In pursuit of their strategic goals, they provided flows of financial and technical assistance to underpin state largesse - permitting Jordan to develop without difficult reforms and cushioning it from the adverse socio-economic impacts of overspending. Donors thus bear some responsibility for the adverse consequences, felt inter alia in the water sector to which much aid has been directed but whose slow pace of reform reflects the workings of the patronage state.

However, the combined effects of the Arab Spring and global financial crisis provided a wake-up call - exposing weaknesses in the monarchy's compact with the people and the contradiction between centralised power and popular demands for democratic reforms.

The Hashemites have historically taken dramatic steps to cope with security threats to the monarchy and state: In 1988, King Hussein severed ties with the West Bank and the next year in response to economic austerity reinstated parliamentary life, both steps contributing to a restructuring of relations with his people. King Abdullah has shown that he, too, is aware that politics cannot stand still if ongoing socio-economic crises are to be dealt with, and that the current patronage state is unsustainable.

\subsection{Proposed Actions}

\subsubsection{Building Water Security Through Political Reforms}

Jordan's government, donors and water specialists publicly recognise that developing water security will be a pre-condition for generating the needed levels of economic growth to meet future energy, food and financial challenges and that failure risks domestic instability, a message strongly delivered in the government's 2005 National Agenda (JMGP 2005). Commitment to water reforms is strong. Yet, despite the fast-deteriorating water situation, Jordan's leaders and their counterparts abroad avoid publicly recognising "the elephant in the room", namely that Jordan's water strategy is politically challenged:

What is missing is frank talk about how the Kingdom's distinctive power dynamics (i) contribute to distorted allocations and unsustainable use; (ii) foster a culture of competition for, rather than conservation of, scarce water resources; and (iii) inhibit efficient and democratic water governance necessary for economic growth, for putting in place adaptive capacity to deal with climate change and for laying the foundation for regional cooperation over shared water resources and new supplies (Yorke 2013, p. 77). 
It follows that the path to sustainable water management will involve both addressing political factors adversely affecting water governance and exploiting opportunities to build well-functioning political and economic systems to improve the context for implementing effective water solutions. Meeting the following criteria will likely determine success:

\section{Recognising Poor Water Governance Reflects a Wider Political Problem} While "shadow state" elites dominate centralised unaccountable structures, reforms will likely continue to show imbalances with the privileged benefiting disproportionately. More representative parliaments would give Jordanians greater political say in, and parliamentary scrutiny over, policies and thus render more likely their acceptance of difficult reforms.

\section{Recognising How Non-water Policies Impact on Water Outcomes and} How Poor Water Governance Affects Other Sectors This will involve national leaders making consideration of how to use scarce water a priority in national planning and investment decisions and aligning its governance with cross-sector policies chosen efficiently and effectively to promote economic growth. Coherent decisions require policymakers to understand how water management affects their sectoral responsibilities and to tap into water-sector expertise, calling for a central single water data set.

\section{Improving Accountability and Transparency, and Curbing Corruption} Good governance across the board will be a pre-condition for improving water management at home, and both will be necessary for building the level of regional cooperation required to manage and protect shared water resources and for attracting foreign investment for water and other projects. Governments that are accountable are incentivised to implement the reforms needed to deliver services in line with public and investor expectations.

\section{Recognising Reforms Must Be Inclusive, Results-Oriented and Well-} Planned Jordanians will be more likely to "buy into" difficult reforms if they can perceive tangible benefits, and to stay the course if they have been consulted.

Restructuring Donor Collaboration If donors are to support an extended reform process, they need reassuring that national leaders are shouldering responsibility in meeting reform-related conditions negotiated. Revised arrangements with donors for cash transfers and their conditions precedent (especially on water use in agriculture) will be key. 
All this suggests a bold political approach linking political and governance reforms to effective water solutions is needed. King Abdullah II's response to the Arab Spring (King Abdullah II Ibn Al Hussein 2012) ${ }^{15}$ provides unprecedented opportunity, when regional politics permit, for Jordan to implement with international support the needed domestic, regional and international policies to make this happen. The key challenge will be whether Jordan's roadmap of political reforms ${ }^{16}$ can translate into politico-economic transitions capable of delivering the democratic freedoms and water-secure future to which Jordanians aspire. This paper's analysis and above criteria suggest success will be contingent on: the gradual but systematic implementation in due course of historic structural change away from the rentier system supporting Jordan's unaffordable patronage state to a participatory democracy based on the rule of law, transparency and accountability; and on all Jordanians leadership, elites and public - "buying into" and putting their weight behind a difficult transition through agreeing cross-sector reforms serving the collective interest and a strategic agenda for implementing political, economic, legal and institutional aspects in which water is prioritised (Yorke 2013, pp. 80-93).

Who would drive these processes? The King has recognised the need for "topdown" leadership to facilitate "bottom-up" reform. By calling on Jordanians to embark on a process of "self-transformation", he has pointed the way through uncharted waters. While offering guidance he has called on Jordanians - government, parliament, administration, NGOs and citizens - to assume responsibility for agreeing a vision for Jordan's future and to drive through inclusive reforms to implement it. In this context, there is need for "political champions" amongst the elite to recognise win-win outcomes for all and to bring their followers with them. Donors must also play their part, with robust support for such political change.

\subsubsection{National and Regional Solutions}

On this paper's analysis and evidence only a political transition based on a restructured partnership between Throne and people will pave the way to the institutional, legal and economic reforms needed for Jordan to sequence implementation of effective water solutions. Meanwhile, Jordan needs as a matter of priority to support on-going ministry efforts to transform its water sector. "Business-as-usual" is not an option. Water management shortcomings render unachievable both the narrowing of water deficits and laying foundation for a sustainable water-secure future. Reforms need to move further and faster than planned. Ideally, they would be facilitated by

\footnotetext{
${ }^{15}$ In 2012-2013, the king outlined goals for "self-transformation and progressive reform": fair parliamentary elections, a law guaranteeing broad representation, a Parliament based on political parties and governments drawn from that Parliament. In 2013, the king distributed three papers on political transition.

${ }^{16}$ Constitutional changes implemented in 2012 and elections held in 2013, to be followed by changes in the electoral law, and formation of governments comprising elected parliamentarians.
} 
timely pursuit of policies to meet the above criteria, which would start to free institutions from patronage politics and empower them. But they cannot wait.

How might this transformation be brought about? In view of the governance shortcomings identified earlier, focus on an integrated cross-sectoral approach incorporating domestic and regional options, which in different combinations could assist Jordan to meet its water challenge in the absence of a large-scale RSDS Conveyance Project offers the best way forward (Yorke 2009, 2013, pp. 94-132). Priorities for immediate implementation - some already embarked upon by the government - are identified below that would meet the criteria earlier set out and assist Jordan through small steps to narrow its short- and medium-term deficits; to protect its aquifers; to extend the period before a bulk solution is required and to identify long-term options for that supply. It is suggested these solutions be pursued in parallel, planned by national decision-makers in consultation with the public, coordinated inter-ministerially, and implemented with an agreed time-line.

\subsubsection{Transforming the Water Sector}

A necessary start point for the new approach would be the formal adoption of integrated planning across government and sectors. This would provide means to ensure that strategically important but scarce water is prioritised, its true cost accounted for and its management aligned with cross-sector implementation of the policies chosen to fulfil growth objectives. The resulting plan, with time-line and benchmarks, would provide frame for the required "step change" in water management.

A switch to integrated planning, reportedly underway, will be technically challenging. Decision-makers will face difficult choices given the food and energy needs of an expanding population, the need to attain higher growth levels and climate change impacts on water availability. It is suggested therefore that as part of the political transition, the king, prime minister and cabinet formally mandate this switch, thereby providing for prioritisation of water in investment decisions and optimisation of its use for future water security. This "game-changing" move would signal to "shadow state" members that new rules of the game will henceforth apply to water allocation and counter public scepticism on government intentions. At the same time, the national dialogue underway would provide opportunity for stakeholders to identify and agree "win-win" solutions that take availability, costs and the needs of the poor into account. These could be fed into planning. Donors could be expected to collaborate with the government to develop institutional capacity to roll out the plan. They could fund, if Jordan wishes: analysis of the true value of water, support for compilation of comprehensive data in a single centralised source, consultancy on options for restructured tariffs targeting subsidies more fairly and for trade policy adjustments on lifting import tariffs on water-thirsty crops (Yorke 2013, pp. 96-97). Power realities in the kingdom will change only slowly, however. The following discussion with proposals for domestic and regional solutions therefore identifies how these might be facilitated by the wider political transition, sequenced over time to neutralise resistance of opponents and maximise stakeholder cooperation, and be supported by regional and international players. 


\subsubsection{Exploiting Scope for Indispensable Demand and Supply-Side Efficiency Measures}

Officials and donors recognise that opportunities exist to improve efficiency on both demand and supply sides. Some would be politically difficult to exploit, but all could potentially find sufficient support to drive them through and are technically and economically feasible. As a package they could bring short to long-term benefits - conserving low-cost supplies, protecting aquifers, enhancing adaptive capacity to climate change, raising additional revenue and making additional water available at lower cost than development of new sources:

\section{Non-Revenue Water Reduction}

A well-recognised opportunity lies in addressing inefficient supply in the municipalities and improving performance to standards that would reduce NRW at the Miyahuna and YWC networks. Politically, the government is committed to NRW reduction and Jordanians understand that failure to address the public health problem of leakages could result in political unrest. In addition leakage reductions and pressure controls at supply networks would reportedly be one of the most costeffective measures to increase water supply and raise revenue (MWI 2009; MWI and WRG 2011). Failure to improve the Amman network (Miyahuna) would raise the cost of Disi water from JD $0.85 / \mathrm{m}^{3}$ to around JD $1.75 / \mathrm{m}^{3}$. Technically, leakage reduction would be a low cost-high volume move (Salameh 2007, p. 9). Technical leakages account for around $50 \%$ of water supplies lost to NRW, but experts say network rehabilitation and improved management could reduce these losses by $50 \%$. On this basis, starting at Miyahuna and YWC, an annual saving of $19.5 \times 10^{6} \mathrm{~m}^{3}$ (based on current production) could be achieved (USAID 2012, p. 32). A countrywide program would require further analysis, but water volumes of around $40 \times 10^{6} \mathrm{~m}^{3}$ annually could potentially be saved by 2025 , a significant contribution to projected requirements. Theft should be tackled in parallel, with the WAJ coordinating closely with the police on law enforcement, and a public education program launched.

The USAID is likely to support NRW projects, but the high cost of infrastructure makes essential a new US-Jordan understanding on USAID cash transfers to infrastructure projects and their ties to the fulfilment of conditions precedent. ${ }^{17}$ Inter alia, conditions would need to cover government moves to rein in theft and shut illegal wells, the extension of PSP to more utilities with tighter performance-based management contracts and tariff restructuring.

\footnotetext{
${ }^{17}$ Echoing views expressed to the author in 2010, the (USAID 2011) found USAID/Jordan had not developed conditions precedent to ensure sustainability of its program activities since 2010 . Criticism focused on the failure to address agricultural water use.
} 


\section{Cross-sector Highlands Water Strategy}

A second opportunity lies in rethinking agriculture in the Highlands, where use of strategically important, low-cost groundwater is controversial. High-volume water use and low productivity point to scope for increasing agriculture's efficiency and contribution to national wealth, for conserving renewable low-cost supplies through sustainable use and for arresting aquifer depletion ${ }^{18}$ whilst enhancing adaptive capacity. ${ }^{19}$ Jordan's political transition and the increased public and parliamentary scrutiny it will bring has put leaders on notice to pursue policies serving the national interest rather than their own vested interests, providing political space for the Prime Ministry and governing institutions to intervene with the required approach to Highlands groundwater management.

Driven by national leaders, this would need to maximise the use of available legal, financial, technical and administrative levers to ensure groundwater is used efficiently and sustainably. It would build on the 2002 By-Law No 85 and would need to involve stakeholders - as did the Highland Water Forum initiative - in its design and implementation and to secure donor funding. A "carrot and stick" approach to win the cooperation of landowners and farmers, or cajole them, to change behaviour ${ }^{20}$ and to assist the poor to adjust might include:

- Enlisting tribal interlocutors to explain the situation and solutions to water users in a culturally sensitive manner. Shadow state members, identifying with the national interest to reduce over-abstraction, would make excellent "political champions" in a collective effort to optimise water use and productivity, according to one interviewee. Measures to improve on-farm efficiency, raise government revenue and avoid social hardship might include:

- Incentives to encourage farmers voluntarily to change crops and production methods or to cease farming in order to reduce groundwater use. Consensus has grown among political elites and landowners on the need for suitable crop patterns. But crop transition will be long term, requiring steps to provide "win-win" outcomes for wealthy and poor farmers and workers. Interventions to ease the transition require study but might include: (a) subsidies, loans and debt forgiveness (Denny et al 2008, p. 11) where farms are profitable and farmers plan behaviour shifts to reduce groundwater use and to generate increased productivity; (b) retirement packages and alternative income opportunities for those unable

\footnotetext{
${ }^{18}$ According to a U.S. Geological Survey report cited in (USAID 2012, p. 7), groundwater abstraction levels have declined over recent years. But they still exceed safe-yield.

${ }^{19}$ Highlands irrigated agriculture is three times less productive than in the Jordan Valley, less profitable and accounted for over half $\left(207 \times 10^{6} \mathrm{~m}^{3} /\right.$ year $)$ of abstracted renewable groundwater, or nearly $25 \%$ of total resources allocated in 2010 (Subah and Habjoka 2011).

${ }^{20}$ The government has been reluctant to press for demand management in the past because this involved confronting influential landowners resisting reforms. Ministry of Agriculture's conservative policy is best understood in this context, though it also strongly champions the poor. The Ministry's cap for overall irrigation use set at $700 \times 10^{6} \mathrm{~m}^{3} /$ year may be politically-doable, but is arguably too high $\left(510 \times 10^{6} \mathrm{~m}^{3}\right.$ in 2010$)$.
} 
to farm at profit. Compensation could be offered in return for well closures. Agribusiness development, eco-tourism, wind and solar projects and expanded rain-fed agriculture could provide reassurance for those who risk losing jobs and opportunity for landowners to diversify investments.

- Parallel inducements to encourage farmers to reduce groundwater abstraction will be essential: (a) phased increases in extraction charges to encourage farmers to shift to higher value, water-efficient-crops or to move to alternative employment and to raise revenue; (b) removal of quantitative restrictions and customs duties on imported water-intensive crops to encourage farmers to grow highervalue, less-thirsty crops to enjoy comparative advantage; (c) accelerated enforcement of the 2002 By-Law No 85 (calling for closure of an estimated 1,000 illegal wells and restrictions on extraction from 2,799 licensed wells).

- USAID financial support. Although USAID projects have not focused on agriculture, this is changing following the highly critical 2011 USAID Audit. USAID could financially facilitate cross-sector studies on crop diversification and the above incentives, but make inducements subject to tightened conditions precedent for cash transfers.

\section{Wastewater Reuse}

Third is the opportunity to increase significantly the levels of treated wastewater for industry and agriculture in order to reduce demand for groundwater in the medium to long term. The option appears feasible: USAID consultants recommend that the agency fund over 5 years the building of medium-sized wastewater treatment plants (WWTPs) (USAID 2012, p. xvi). The option is politically attractive on account of its environmental and public health benefits and is technically feasible.

Expanding wastewater treatment is likely to be key to reducing highlands groundwater use and to long-term plans to release surface water (used in irrigation) for municipal use. Research is required on what volumes of treated wastewater might realistically be produced. This article's projections foresee around $60 \times 10^{6} \mathrm{~m}^{3} /$ year of additional treated wastewater production by 2020 and $85 \times 10^{6} \mathrm{~m}^{3} /$ year by $2025^{21}$ - a significant contribution to closing projected deficits.

\subsubsection{Pursuing Affordable Regional Desalination}

Jordan has long recognised that water solutions cannot be exclusively national. This is because even when improvements in demand and supply efficiency and the remaining feasible new water options (wastewater re-use and brackish water

\footnotetext{
${ }^{21}$ Figures exclude supplies from As Samra extension for which finance is committed.
} 
desalination) are taken into account, significant additional supplies will be required to narrow remaining deficits - whether from desalination, regional conveyance or transboundary solutions; and if these projects are to succeed, they will require international involvement - funding, provision of data, legal frameworks and guarantees. Meanwhile the global financial crisis, climate change, Arab uprisings and conflict in Syria and Iraq have transformed the political landscape, pushing Jordan's allies to reshape Middle East policies in which quid pro quos in exchange for the political and material support they extend will play a part. In short, past circumstances underpinning Jordan's rentier state are falling away and unilateral "business-as-usual" water policies based on it no longer hold. National leaders recognise the need radically to rethink how they address bulk-water supply and regional cooperation, if Jordan is to find a path to a water-secure future.

The government's preferred option has been desalination on its own coast. In December 2012, in a changed approach reflecting national interest, it refocused on the long-studied RSDS Conveyance Project, having decided to "scale down" its ambitious but unaffordable Jordan Red Sea Project (JRSP) in favour of a $70 \times 10^{6} \mathrm{~m}^{3} /$ year desalination plant near Aqaba (Namrouqa 2012). The plant, which experts say is technically feasible if built north of the airport, will be designed to meet requirements for growth in the south over the medium term and - as agreed in December 2013 with Israel and the PA - transboundary demand in Israel and Palestine (see below). With its regional cooperative aspects, funding is likely to be forthcoming. However, discharge of the brine is problematic: Environmentalists argue against piping brine to the Dead Sea. On the other hand, any plan to discharge brine in the Gulf of Aqaba would need a positive environmental assessment and a mandate from riparian states. ${ }^{22}$ The alternative of distributing brine in the desert requires study.

Jordan hoped the new plant would serve as the first phase of the mega-RSDS Conveyance Project. This latter project by virtue of Israeli, Jordanian and Palestinian participation, would likely have attracted international funding, permitting Jordan to sell a proportion of the more than $370 \times 10^{6} \mathrm{~m}^{3} /$ year of water earmarked for it at prices affordable to Jordanians. Moreover, though not publicly discussed by decision-makers, it could have secured these outcomes without the government having to implement politically difficult water and economic reforms that alternative solutions would require. The recent World Bank-funded RSDS feasibility study raised questions over the project's technical feasibility, however, and environmentalist opposition now points to its potential abandonment. Jordan is thus in need of a Plan B for its long-term bulk supply, which has led some to resuscitate the politically difficult option of conveyance of desalinated water from the Mediterranean coast. But there are regional alternatives to this, as discussed below.

\footnotetext{
${ }^{22}$ Jordan, Saudi Arabia, Egypt and four other riparian states are members of the Regional Organisation for the Conservation of the Environment of the Red Sea and Gulf of Aden which is committed to conservation of coastal and marine environments.
} 


\subsubsection{Intensifying Regional Diplomacy to Manage Shared Resources}

Jordan's water policy for decades has reflected asymmetry of power with its neighbours and its downstream riparian status. Lacking leverage to enforce its rights over shared surface waters, it has preferred unilateral options to secure new supply. However, in view of the scale of the water crisis, Jordan has strong interest in reaping the benefits of regional cooperation, for it will be a pre-requisite for the success of its mix of short-, medium- and long-term water solutions. A multi-pronged approach is required to facilitate regional and transboundary cooperation in order to mitigate dangers to shared waters and to develop new resources. Albeit less powerful than its neighbours, Jordan may not be maximising what leverage it has. Smart diplomacy could lead to beneficial trade-offs over water, food and energy. Besides, insufficient attention to bilateral differences might permit these to fuel broader tensions.

Since it is in the region that medium- and long-term water security will be found, now is the time for Jordan to raise the profile of water in diplomacy and harness support for indispensable regional efforts to manage resources sustainably - within and inter-basin. Identified below are four areas for cooperation which would serve the interests of Jordan and its neighbours. Requiring national and regional action, they cover demand and supply aspects and could be effective in the short to long term. All are in the public domain and given the right political dynamics would be feasible.

\section{Laying Foundations for a Regional Water Authority}

The promotion of the idea of a Council for Water Resources in the Middle East made up of heads of government represents a start (SFG 2011, p. 20). The Council's purpose would be to support five countries - Jordan, Iraq, Lebanon, Turkey and Syria - to prepare for decisions around water through reaching consensus on principles of cooperation, developing guidelines for standardising measurements, interpreting and exchanging data, on measures to combat climate change and setting targets for sustainable water management. In pursuit of these goals, the new High Level Group chaired by HRH Prince Hassan bin Talal ${ }^{23}$ provides a platform for fresh thinking on interdependencies; and it can drive regional interactions until leaders agree to raise these to institutional level - in the form of a Regional Water Authority. Such collaboration would likely generate momentum behind the strategies discussed next, which if successful, would positively influence Jordan's water outcomes.

\footnotetext{
${ }^{23}$ The group comprises a former Turkish foreign minister and Lebanese finance minister and will in due course include Iraqi and Syrian representatives.
} 


\section{Pursuing Transboundary Cooperation to Close the Medium-Term Deficit}

Jordan will need to maintain the quantities of transboundary water it receives, ensure it receives its rightful shares and find ways to increase them. This provides incentive for improving cooperation with Syria, Israel and Saudi Arabia. Present uneasy relations prevent cross-border supervision, the minimum required for successful water sharing. Moreover, current allocation accords ${ }^{24}$ are fragile - complicated by mutual distrust and vulnerable to climate-change impacts. Regional politics are in flux, so it will be important for Jordan to maximise opportunities for diplomacy and cooperation over shared water - with regard to technology, water data or wider energy, trade and transit deals which would likely win international support.

It is too early to know Syria's political future, but its people will need to rebuild their country, a process from which Jordan could benefit when it renews relations. At that stage it will have strong incentive to prioritise water and press for a new accord that irons out differences over Yarmouk resources and provides for water sharing and joint cooperation over maintenance of water quality and pollution prevention. Experts suggest Jordan could push for a larger share than originally agreed - say $100 \times 10^{6} \mathrm{~m}^{3} /$ year.

Twenty years after the 1994 Jordan-Israel Peace Treaty commitment to augment water supplies to Jordan by $50 \times 10^{6} \mathrm{~m}^{3} /$ year, a formula has been found. Under the recent Jordan-Israel-PA accord, Jordan will sell Israel up to $50 \times 10^{6} \mathrm{~m}^{3} /$ year from the proposed Aqaba desalination plant in exchange for Israel's sale to Jordan of an additional $50 \times 10^{6} \mathrm{~m}^{3} / y e a r$ to be released from Lake Tiberias in the north to supply Amman. The likelihood of access to international funding will reduce the costs to Jordan. The arrangement, which will contribute directly or through exchange up to $70 \times 10^{6} \mathrm{~m}^{3} /$ year to Jordan's medium-term deficit, is an encouraging precedent for further joint projects.

One such would be a Jordan-Israel-PA application to UNESCO for World Heritage Site recognition for the Jordan River/Dead Sea - an idea already considered in Amman. An application, if it is to succeed, would need to specify what responsibilities the participants would assume for joint management of the shared water course flowing to the Dead Sea and agreeing plans for the sustainable use of waters allocated. ${ }^{25}$ A successful application could provide unimaginable "win-win" outcomes for riparians, including mechanisms to cooperate over rather than compete

\footnotetext{
${ }^{24}$ In 1987 Syria agreed to supply Jordan with $208 \times 10^{6} \mathrm{~m}^{3} /$ year but Jordan reportedly receives only $50-100 \times 10^{6} \mathrm{~m}^{3} /$ year, and in drought years less. Experts say Syria has dug thousands of dams which deprive Jordan of its rightful share. Under the 1994 Israel-Jordan Peace Treaty, Israel is obligated to release $100 \times 10^{6} \mathrm{~m}^{3} / \mathrm{y}$ ear to Jordan, but actual releases are closer to $50-60 \times 10^{6} \mathrm{~m}^{3} /$ year, reports the MWI Water Budget, 2012.

${ }^{25}$ Arab parties would need to consult with members of the Jordan River Initiative for Cooperation, which is committed to the Convention on the Law of the Non-Navigational Uses of International Water courses.
} 
for precious river water, to protect the environment and to access political and financial support for projects to protect the Dead Sea and Jordan River. This degree of cooperation could encourage international parties to consider how they might support regional water supply projects for Jordan (and Palestine) through bulk conveyance, which are considered next.

\section{Supporting Studies on Inward Transfer of Turkish Water}

With Jordan's long-term need for bulk water, exploring the potential for the import of Turkish water (Gruen 2007; Wachtel and Liel 2009; IPCRI 2010; Yorke 2013, pp. 127-131) has become a priority as prospects for the mega RSDS Conveyance Project wane. Turkey would like to export water to the extent it has capacity (SFG 2011, pp. 39-41) and has historically favoured Middle East destinations for political reasons. The SFG's initiative to build cooperation around water between Turkey and the Arab states is therefore crucially important. Diplomacy and studies could keep open the option of water transfer to Jordan and its neighbours in the face of competing purchase offers from Mediterranean countries and lead to related deals on the transport of gas, oil and electricity to underpin growth. Given the potential contribution of Turkish water to Jordan's ability to meet long- and even medium-term needs, studies of the options deserve technical and financial support:

- Transfers from Manavgat River: Most promising would be Jordan's purchase of water conveyed from Turkey's Manavgat facility by tanker or floating bag. Imports of up to $400 \times 10^{6} \mathrm{~m}^{3} /$ year would be significant and could be negotiated as part of a set of bilateral accords with Turkey or as a regional package involving Israel, or as a straightforward purchase of potable water for the medium term, pending a long-term solution. Conveyance by tanker is considered technically more reliable than by bag. ${ }^{26}$

- Transfers from the Seyhan and Ceyhan Rivers: Turkey's past interest in the idea of a pipeline to Syria and Jordan (Gruen 2007; Rende 2007; Wachtel and Liel 2009) has receded since development around the rivers has dented export capacity. Still, an estimated $1,000-1,500 \times 10^{6} \mathrm{~m}^{3}$ would be available to 2020 , though flows would be intermittent. A modified pipeline in the context of a possible future Marshall-type plan for Syria's reconstruction with international guarantees and a legal framework might therefore appeal to all parties as well as attract the needed funding. The plan's self-sufficiency in terms of energy to convey the water would be an added plus. Scientific analysis to identify the scale of Turkey's future export capacity would be required as well as commitments by participating countries on joint monitoring and management.

- A third option would be an undersea network of pipelines through the Mediterranean to carry water, gas, oil and fibre optics (Personal interviews 2010;

\footnotetext{
${ }^{26}$ For discussion on Spragg bag technology, see www.internationalwaterlaw.org/blog/category/ middle-east
} 
(IPCRI 2010). Though politically easier to implement and less costly than other bulk water projects, the option is not technically feasible due to the Mediterranean's depth. Studies on how to overcome this difficulty and cost comparison with conveyance by transport or bag from the Manavgat are proposed.

\subsection{Conclusion}

Taken together, the above options for water solutions, if implemented, could assist Jordan to close the medium and long-term deficits projected in this chapter, conserve low-cost renewable resources for medium-long term use, protect aquifers, enhance adaptive capacity against climate change and find a bulk-supply solution as an alternative to a mega RSDS Conveyance Project. They involve: (a) demand and supply-side improvements at home - reduction and more efficient use of groundwater, conservation of these low cost renewable resources for mediumlong term use, increased wastewater treatment for agricultural use and non-revenue water reduction; (b) building a desalination plant in Aqaba; (c) access to higher volumes of surface water from Syria and Israel and the conveyance of bulk supplies from Turkey. A pessimistic scenario would be one where Jordan fails to reach a favourable deal in the next couple of years with Syria on Yarmouk waters and no regional bulk-supply project, via imports from Turkey, is developed by 2025/2026.

Realistically, there is no set of local and regional policies that can guarantee the delivery of water to Jordan at affordable prices over the long term in sufficient quantity for it to fulfil its economic aspirations. Many factors beyond Jordan's control will inevitably influence prospects and access to water will remain highly political domestically and regionally. What is clear is that finding a path to future water security will depend on Jordan accelerating a nationwide coordinated approach to parallel political, economic and water reforms and on a new imaginative regional diplomacy that boosts indispensable cooperation over water, economic and trade issues - the two are linked. International donors can be expected to support their strategic ally in its endeavour. The policy options discussed in this chapter could improve Jordan's water sector sustainability and through making additional supplies available relieve the pressures of water scarcity until long-term bulk supplies are found. The need to find a solution to the Arab-Israel conflict and to assist Syria move to a peaceful transition that would permit hundreds of thousands of refugees in Jordan to return will be determining factors.

Open Access This chapter is distributed under the terms of the Creative Commons Attribution Noncommercial License, which permits any noncommercial use, distribution, and reproduction in any medium, provided the original author(s) and source are credited. 


\section{References}

Allan JA (2003) Virtual water eliminates water wars? A case study from the Middle East. In: Hoekstra AY (ed) Virtual water trade. Proceedings of the international expert meeting on virtual water trade. IHE Delft, The Netherlands, pp 137-145

Alon Y (2009) The making of Jordan: tribes, colonialism and the modern state. I.B. Tauris \& Co. Ltd, London

Alterman JB, Dziuban M (2010) Clear gold: water as a strategic resource in the Middle East. A report of the CSIS Middle East program. http://csis.org/files/publication/101213_Alterman_ ClearGold_web.pdf. Accessed 14 Jan 2015

Coyne et Bellier (2012) Red Sea - Dead Sea water conveyance study program. Draft final feasibility study report

Denny E, Donnelly K, McKay R et al (2008) Sustainable water strategies for Jordan. http://www. umich.edu/ ipolicy/PolicyPapers/water.pdf. Accessed 14 Jan 2015

Fischbach MR (2000) State, society and land in Jordan. Brill Academic Publishers, Leiden/Boston/ Köln

FOEME (2010) Towards a living Jordan River: an economic analysis of policy options for water conservation in Jordan, Israel and Palestine. Friends of the Earth Middle East, Amman

Gruen GE (2007) Turkish water exports: a model for regional cooperation in the development of water resources. In: Shuval H, Dweik H (eds) Water resources in the Middle East: IsraelPalestinian water issues - from conflict to cooperation. Springer, Berlin, pp 157-164

Hagan RE (2008) Strategic reform and management of Jordan's water sector. USAID Jordan, Amman

GIZ (Deutsche Gesellschaft für Internationale Zusammenarbeit) (2011) The Highland Water Forum: a multi-stakeholder dialogue for sustainable groundwater management in Jordan. Amman.

IPCRI (2010) Water imports - an alternative solution to water scarcity in Israel, Palestine and Jordan? Palestine Center for Research and Information, Jerusalem

JME (2009) Jordan's second national communication to the United Nations Framework Convention on Climate Change (UNFCCC). Jordan Ministy of Environment, Amman

JMGP (2005) The national agenda 2006-2015: the Jordan we strive for. Jordan Ministry of Government Performance, Amman

Jordan-Israel Peace Treaty (1994) Treaty of peace between the state of Israel and the Hashemite Kingdom of Jordan (including texts of Annex II - water and Annex IV - environment), 26 October 1994. http://foeme.org/www/?module=regional_data\&record_id=3. Accessed 3 Feb 2015

King Abdullah II Ibn Al Hussein (2012) Discussion Papers His Majesty King Abdullah II Ibn Al Hussein. http://kingabdullah.jo/index.php/en_US/pages/view/id/244.html. Accessed 27 Jan 2015

Muasher M (2011) A decade of struggling reform efforts in Jordan: the resilience of the rentier system. http://carnegieendowment.org/files/jordan_reform.pdf. Accessed 3 Feb 2015

MWI (2009) Water for life: Jordan's water strategy 2008-2022. http://www.irinnews.org/pdf/jordan_national_water_strategy.pdf. Accessed 14 Jan 2015

MWI, WRG (2011) Confidential Paper. Amman

MWI (2012) Water budget: projected demands and resources 2010-2025. Jordan Ministry of Water and Irrigation, Amman

Namrouqa H (2012) Southern agricultural companies still operating despite cancelled contracts former minister. In: The Jordan Times. http://jordantimes.com/southern-agriculture-companiesstill-operating-despite-cancelled-contracts. Accessed 9 Apr 2015

Peters A, Moore P (2009) Beyond boom and bust: external rents, durable authoritarianism, and institutional adaptation in the Hashemite Kingdom of Jordan. In: Studies in comparative international development, Springer science. Springer, Piscataway, pp 256-285 
Rende M (2007) Water transfer from Turkey to water-stressed countries in the Middle East. Water resources in the Middle East: Israel-Palestinian water issues - from conflict to cooperation. Springer, Berlin, pp 165-173

Salameh E (2007) Towards a water strategy for Jordan. Royal Committee on Water, Amman SFG (2011) The blue peace: rethinking Middle East water. Strategic Foresight Group, Mumbai

Subah A, Habjoka N (2011) The highland water forum: an experience in participatory water demand management. Paper presented at the economics of water demand management in Jordan workshop, Amman, 3 Dec 2011

Tripp C (2007) A history of Iraq. Cambridge University Press, Cambridge

USAID (2011) Audit of USAID/Jordan's design for sustainability in its water resources. U.S. Agency for International Development, Cairo

USAID (2012) Review of water policies in Jordan and recommendations for strategic priorities, final report. U.S Agency for International Development, Amman

Wachtel B, Liel A (2009) The "Peace Canal on the Golan" proposal: benefits and risks for regional water cooperation in the Middle East. In: Lipchin C, Sandler D, Cushman E (eds) The Jordan River and Dead Sea Basin: cooperation amid conflict. Springer, Dordrecht, pp 235-253

World Bank (2007) Making the most of scarcity: accountability for better water management results in the Middle East and North Africa. http://siteresources.worldbank.org/ INTMNAREGTOPWATRES/Resources/Making_the_Most_of_Scarcity.pdf. Accessed 27 Jan 2015

Yorke V (1988) Domestic politics and regional security: Jordan, Syria and Israel - the end of an era? Gower Press/IISS, London

Yorke V (1990) A new era for Jordan? World Today 46:27-31

Yorke V (2009) Jordan water scarcity, strategy and alternative solutions: a politico-economic perspective. Paper presented at NCCR Trade Regulation Workshop, World Trade Institute, Bern, 27 November 2009

Yorke V (2013) Politics matters: Jordan's path to water security lies through political reforms and regional cooperation. Commissioned by NCCR-Trade Regulation, World Trade Institute, Bern 